\title{
PROSPECTS FOR IMPLEMENTING PARTICIPATORY BUDGETING AS AN EFFECTIVE INSTRUMENT FOR IMPLEMENTING BUDGETARY POLICY AT THE LOCAL LEVEL
}

\author{
Natalia Sirenko', Olga Melnyk², Nataliia Shyshpanova ${ }^{3}$ \\ Mykolayiv National Agrarian University, Ukraine
}

\begin{abstract}
The purpose of the study is to determine the methodological principles for implementing Participatory Budgeting as an effective instrument of the budgetary policy at the local level, in particular, the analysis of the main risks and limitations of this process, the identification of its main stages and the features of the main types of activity, which includes each stage. Methodological bases of the study consist of general scientific methods of obtaining knowledge of economic phenomena and processes. Realization of study tasks requires the following methods: method of theoretical generalization - during the study of scientific works, regulatory legal acts; abstractlogical method - to generalize the theoretical and methodical provisions, as well as to determine the purpose of the study; method of a systematic approach - the definition of directions for improving the functioning of Participatory Budgeting as an effective instrument for implementing budgetary policy. Results. The main components, which should include Participatory Budgeting process are proposed, the purpose of which is to facilitate the establishment of a social dialogue between local authorities and residents of the territorial community, and to create conditions for the participation of the residents of the territorial community in the budgetary processes to meet their needs. The analysis of the conducted studies made it possible to determine the main risks and limitations of participatory budgeting. Practical implications. The main stages of the participatory budgeting process are outlined, in particular: the preparatory stage, the stage of budget formation and its approval, the main point of which is the establishment of a budget committee and the commencement of its work, the implementation stage, the stage of monitoring and evaluation of participatory budgeting. The main types of activity included in each stage have been studied. All of the above made it possible to develop a cycle of participatory budgeting as one of the directions of budgetary policy. We believe that the popularity of this process is determined by the benefits received by the residents, local authorities and the city in general. Value/originality. Formation and implementation of budgetary policy at the local level in the current conditions of decentralization of power with the help of the developed cycle of implementation of Participatory Budgeting will promote the establishment of a social dialogue between local authorities and residents of the territorial community, creating conditions for the participation of residents of the territorial community in a transparent budgetary process to meet their needs.
\end{abstract}

Key words: budgetary system, budget, budget of participation, fiscal policy.

JEL Classification: G18, H61

\section{Introduction}

The budget is an inalienable attribute of each country and an important instrument for implementing the economic and social policies of the state. Today, the problem of constructing a perfect and effective system for the formation of budgetary policy and ensuring transparency of the budgetary process is becoming especially topical. Modern trends taking place in the budgetary system of Ukraine in the conditions of decentralization of power determine the necessity of introducing new instruments of budgetary policy implementation. Investigating modern changes and initiatives in the sphere of decentralization of power both in the world and in Europe, one can notice a tendency of involving citizens in the process of direct impact on the functioning of those settlements, in which they

\footnotetext{
Corresponding author:

${ }^{1}$ Department of Finance, Banking and Insurance, Mykolayiv National Agrarian University.

E-mail: sirenko@mnau.edu.ua

${ }^{2}$ Department of Finance, Banking and Insurance, Mykolayiv National Agrarian University.

E-mail: melnykolga19@gmail.com

${ }^{3}$ Department of Finance, Banking and Insurance, Mykolayiv National Agrarian University.

E-mail: shishpanova@mnau.edu.ua
} 
work and live. Citizens are given the opportunity to take a direct part in the distribution and use of budgetary funds.

The problems of involving the public in the budgetary process and ensuring its transparency are to some extent considered in the works of domestic scientists, such as: I. Lunina (2014), Zh. Belets (2016), O. Demianchuk (2016), T. Kravchenko (2015), N. Buletsa (2016), and others. The aforementioned problems are actively studied in western scientific literature; in particular, the question of the functioning of participatory budgeting is studied in the writings of Polish economists R. Hurskyi, V. Kenblovskyi, B. Martel and other. However, without diminishing the importance of the results obtained, it should be noted that it is expedient to determine the methodological principles to implement Participatory Budgeting as an effective instrument of budgetary policy at the local level.

\section{Foreign experience in the implementation of Participatory Budgeting}

The concept of direct involvement of citizens in the budgetary process is relatively new in the world. For the first time, the practice of Participatory Budgeting was implemented in 1989 in the Brazilian city of Porto Alegre (see Belets Zh., 2016). As a result of the implementation of Participatory Budgeting, civil activity has increased significantly, and the United Nations Human Settlements Programme (UN-Habitat), which seeks to promote sustainable urban development, has announced the experiment with the "public budget" as the best international practice (see Lunina, 2014).

It is important to note that in some countries, different names for Participatory Budgeting are used. So, in Ukrainian practice, there are the notions of "Participatory Budgeting", "Participative Budget", and "Budget for Citizens". We would like to emphasize the fact that the process deserves to be called the Participatory Budgeting determines the basic principle real engagement of citizens in making budget decisions.
Domestic and foreign scientists highlight the most important principles of Participatory Budgeting (Fig. 3).

We believe that adherence to certain principles of Participatory Budgeting will make it possible to really involve citizens in making budget decisions.

In 2010, the idea of implementing the first participatory budgeting appeared in Poland within the framework of the Sopot Development Initiative, an informal group operating in Sopot, in order to fulfil the requirements of sustainable development and increase public participation. To date, more than 1500 cities in the world have implemented the mechanism of participatory budgeting. However, the amount of funds allocated for the distribution of citizens depends on the specifics of the established procedure of a particular country. In Table 1, we provide data on the amount of funds allocated for distribution by citizens in some countries of the world.

Table 1

The amount of funds allocated for distribution by citizens in some countries of the world, 2017

\begin{tabular}{|l|c|c|}
\hline \multicolumn{1}{|c|}{ City (country) } & $\begin{array}{c}\text { Year of program } \\
\text { launch }\end{array}$ & $\begin{array}{c}\text { Amount of funds } \\
\text { allocated to Participatory } \\
\text { Budgeting }\end{array}$ \\
\hline Cologne (Germany) & 2007 & $\begin{array}{c}100 \text { thousand EUR for } \\
\text { each district }\end{array}$ \\
\hline Chicago (USA) & 2010 & $\begin{array}{c}1.32 \text { million USD for } \\
\text { each district }\end{array}$ \\
\hline New-York (USA) & 2011 & 40 million USD \\
\hline Gdansk (Poland) & 2013 & 3 million EUR \\
\hline Paris (France) & 2014 & 100 million EUR \\
\hline
\end{tabular}

Source: prepared using information from the sites of the city councils and the Internet platform of Participatory Budgeting

Thus, the positive experience of many countries in the world and the peculiar style for activating public participation make it possible to conclude that the idea of introducing "Participatory Budgeting" becomes a powerful instrument for implementing budgetary policy in conditions of territorial decentralization of power.

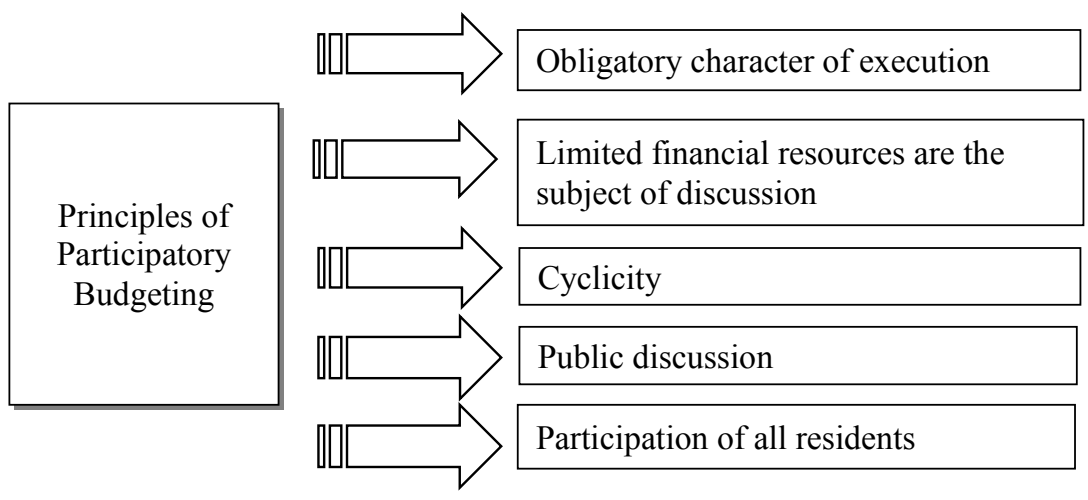

Figure 3. Principles of Participatory Budgeting realization

Source: prepared by the author based on (Hrynchuk, 2016) 


\section{Positive results of implementation}

In 2015, three cities - Cherkasy, Chernihiv, and Poltava - began to introduce the practice of Participatory Budgeting for the first time in Ukraine (see Electronic resource http://ngonetwork.org.ua). This was done, in particular, with the support of the Polish-Ukrainian Cooperation Foundation PAUCI and within the framework of the Polish-Canadian Democracy Support Program.

In Chernihiv in 2015, 4.8 million UAH were allocated, which during the year 2016 were allocated for the implementation of 17 projects. In Cherkasy, in 2015,54 projects were submitted, 6 of which were selected after consideration by the Coordination Council and to date, they are at the stage of implementation. In Poltava, $0.1 \%$ of the total city budget is provided without taking into account transfers (in 2016 it is about 1.5 million $\mathrm{UAH}$ ), of which $50 \%$ is directed to city projects and $50 \%$ to regional ones (see Electronic resource http://ngonetwork.org.ua). In general, Participatory Budgeting has been introduced or is planned to be implemented in more than 50 cities in Ukraine today.

In most cities, there is a division of projects into large and small ones. At the same time, on average 200250 thousand UAH is allocated for one small project and from 250 thousand UAH to 1 million UAH - for large ones. The ratio of funding projects within one budget is $60 \%$ for small and $40 \%$ for large projects. It is worth noting that most cities have chosen a 16-year age requirement for project authors and voters and registration in the city where the campaign is being conducted. Only in the 8 regional centres, the age limit is 18 years (Odesa, Dnipro, Zhytomyr, Ivano-Frankivsk, Lutsk, Khmelnytskyi, Kharkiv, and Cherkasy). The youngest age requirement is in Mykolaiv, where residents who have reached the age of 14 can take part in the participatory budgeting. We believe that low age requirement help to attract young people directly to take part in the life of the city (see Electronic resource http://ngonetwork.org.ua).

In Table 2, we present the regional peculiarities of the implementation of Participatory Budgeting.

Having carried out a research on the results of the implementation of Participatory Budgeting in the cities of Ukraine, we note the characteristic features of this process:

- creation of an effective mechanism of interaction between executive bodies and city residents in the budgetary process;

- increasing the level of transparency of the decisionmaking process by providing residents with the opportunity to directly influence budgetary policy;

- participatory budgeting constitutes a part of the city budget;

projects must be implemented during the fiscal year and only in the territories that the city has the right to dispose of in accordance with the current legislation (Kravchenko, 2015).

Next, we will analyse the amount of budgetary funds for financing the Participatory Budgeting projects (Table 3).

Having analysed the data of Table 3 , it should be noted that the amount allocated for the implementation of Participatory Budgeting projects in the regional centres of Ukraine ranges from 2.0 million UAH in Khmelnytskyi to 150 million UAH in Kyiv. It should also be noted that the largest number of submitted projects for the implementation in 2018 was registered in Kyiv ( 809 projects) and in Lviv (297 projects). It should be

Table 2

Regional peculiarities of implementation of Participatory Budgeting in the cities of Ukraine

\begin{tabular}{|l|l|c|}
\hline \multicolumn{1}{|c|}{ Cities } & \multicolumn{1}{|c|}{ Peculiarities } & $\begin{array}{c}\text { Selection requirement } \\
\text { for participation }\end{array}$ \\
\hline Dnipro & $\begin{array}{l}\text { Participatory Budgeting clause clearly identifies the areas in which projects may be } \\
\text { submitted: security and public order, landscaping and infrastructure, energy conservation, } \\
\text { culture and tourism, communal services, environment, education, healthcare, social } \\
\text { protection, sports and telecommunications, communications and information technology. }\end{array}$ & 18 years \\
\hline Ivano-Frankivsk & $\begin{array}{l}\text { At the beginning of the calendar year, it is mandatory to hold public debates on the } \\
\text { priorities of the city development and identify problems - the themes of projects. }\end{array}$ & 18 years \\
\hline Mykolaiv & $\begin{array}{l}\text { Residents of the city who due to physical peculiarities do not have an opportunity to fill } \\
\text { out the voting form by themselves or personally vote at the polling stations, have the right } \\
\text { to use the help of their relatives and other persons, instructing them to submit a completed } \\
\text { voting form. }\end{array}$ & 14 years \\
\hline Odesa & $\begin{array}{l}\text { Voting is conducted exclusively in electronic form, which significantly limits the range of } \\
\text { potential participants to only active Internet users. }\end{array}$ & 18 years \\
\hline Uzhhorod & $\begin{array}{l}\text { The procedure is exceptionally electronic, but residents have a choice between voting } \\
\text { through an electronic system or through a terminal in the Centre for Administrative } \\
\text { Services Provision. }\end{array}$ & 16 years \\
\hline Lutsk & 18 years \\
\hline Kharkiv & & 18 years \\
\hline
\end{tabular}

Source: prepared on the basis of data (Electronic resource http://ngonetwork.org.ua) 
Table 3

The amount of budgetary funds for financing the Participatory Budgeting projects

in the regional centres of Ukraine for $\mathbf{2 0 1 8}$

\begin{tabular}{|l|c|c|}
\hline Regional centres & $\begin{array}{c}\text { Amount allocated to } \\
\text { Participatory Budgeting, } \\
\text { million UAH }\end{array}$ & $\begin{array}{c}\text { Number of } \\
\text { submitted } \\
\text { projects }\end{array}$ \\
\hline Vinnytsia & 7 & 39 \\
\hline Lutsk & 10 & 14 \\
\hline Dnipro & 16 & 271 \\
\hline Zhytomyr & 12.1 & 99 \\
\hline Uzhhorod & 10 & 79 \\
\hline Zaporizhzhia & 10 & 72 \\
\hline Ivano-Frankivsk, & 2.5 & 0 \\
\hline Kyiv & 150 & 809 \\
\hline Kropyvnytskyi & 5 & 48 \\
\hline Lviv & 20 & 297 \\
\hline Mykolaiv & 10 & 117 \\
\hline Odesa & 100 & 141 \\
\hline Poltava & 5 & 81 \\
\hline Rivne & 10 & 66 \\
\hline Sumy & 9 & 68 \\
\hline Ternopil & 9 & 82 \\
\hline Khmelnytskyi & 2 & 109 \\
\hline Cherkasy & 10 & 76 \\
\hline Chernivtsi & 10 & 100 \\
\hline Chernihiv & 9.5 & \\
\hline
\end{tabular}

Source: prepared on the basis of data (Electronic resource https://www.voting.in.ua)

noted that Kherson is the only regional centre, in which Participatory Budgeting has not been adopted.

Thus, the analysis showed that Ukraine needs to increase opportunities for public participation in the budgeting process at the local and regional level, improving communication between citizens and local authorities in order to improve the efficiency of the process of allocating budgetary resources.

\section{Methodological principles of implementation of Participatory Budgeting}

We believe that a well-conducted process of implementing the Participatory Budgeting should, first of all, contribute to improving the quality of life of the whole city. In addition, Participatory Budgeting should be a part of the reform of local self-government, which provides for the possibility for citizens to dispose of a small part of public funds. Thanks to the long-term model of Participatory Budgeting, cooperation and interest in public opinion, it is possible to achieve longterm results: rationalization of public expenditures, construction of public-private partnership, realization of citizens' expectations.

We have proposed a conceptual model of Participatory Budgeting (Fig. 2).

We believe that the main objective of Participatory Budgeting is to facilitate the establishment of a social dialogue between local authorities and residents of the territorial community and to create the conditions for the participation of the residents of the territorial community in the budgetary processes to meet their needs.

However, as well as any process involving economic and social interference, Participatory Budgeting has its own limitations and risks.

In our opinion, one of the main limitations is related to the specifics of social activity, when most citizens are

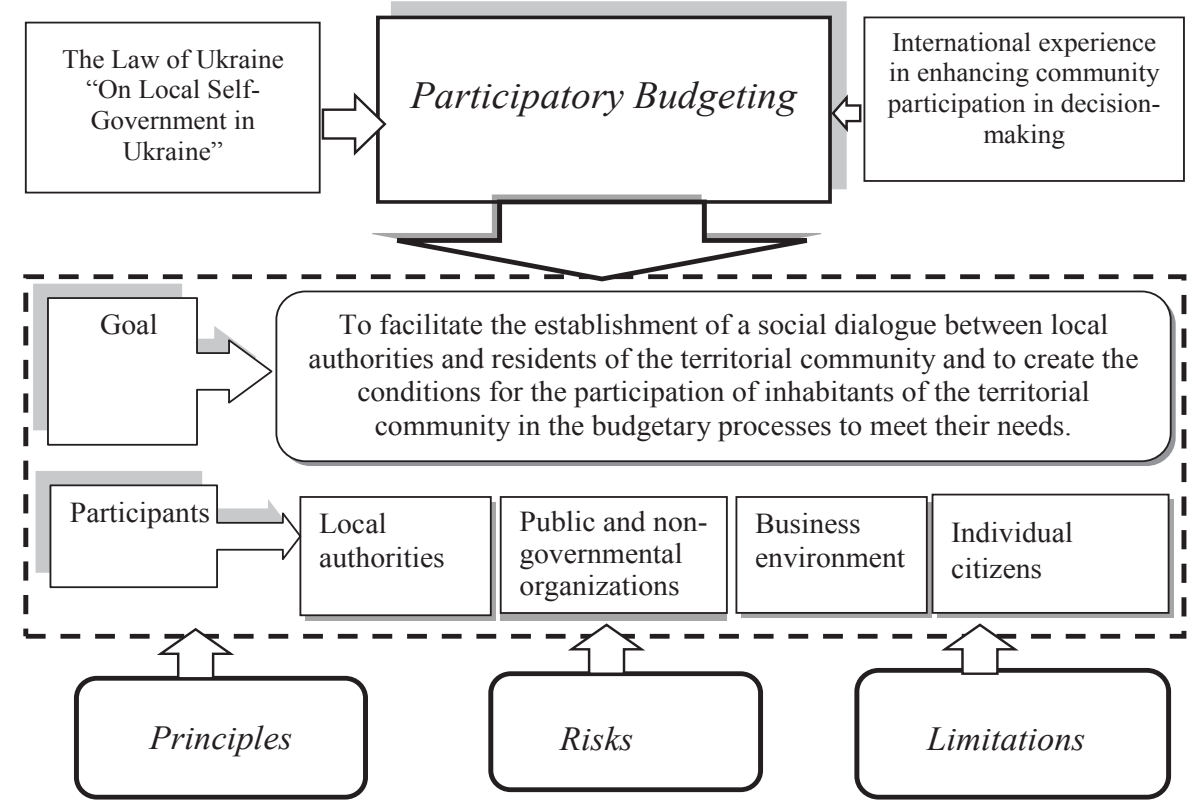

Figure 2. A conceptual model of Participatory Budgeting

Source: prepared by the author 
less interested in studying the rights, fiscal responsibility of the government, etc. than in obtaining and developing a particular infrastructure project.

Another limitation is the dependence of citizens on the administration of the region since it is the local authorities that organize the meeting, provide information, provide meetings of officials with citizens and guarantee the implementation of a certain policy.

In our opinion, the main risks of the implementation of Participatory Budgeting are:

1. Expenditure limitation. For the implementation of Participatory Budgeting projects, only a certain part of local budget revenues is allocated.

2. The weakening of the law. In particular, the experience of Brazil in the field of participatory budgeting suggests that the local authorities were weakened due to parallel participatory processes with the executive branch.

3. The escalation of conflicts related to the distribution of resources among the population involved in the implementation of participatory budgeting. Interest groups can view this process as a place to compete for resources and participate in it for that purpose.

4. "Usurpation" of participatory processes by the local elite. Participation in the process of participatory budgeting, which is accompanied by decentralization, can give the local elite more opportunities to benefit from the budget, despite increasing public control.

However, despite the risks and limitations, we believe that the popularity of this process is determined by the benefits received by the residents, local authorities, and the city in general. Consequently, the participatory budgeting is the most effective decision-making instrument at the local level, because residents not only determine the investment priorities that will be implemented by local authorities but also actively participate in the management of budgetary resources.

\section{Stages of Participatory Budgeting implementation}

The preliminary analysis of the theory on Participatory Budgeting made it possible to determine the sequence of stages of its regulation (Fig. 3 ), with the distinction of the main activity at each stage, which is mandatory for implementation.

The following steps should be taken at the preparation stage. Firstly: dissemination of information about the participatory budgeting; secondly: conducting a situational analysis and problem analysis; thirdly: carrying out activities to ensure that participants in the process understand the principles of decision-making throughout the whole process of budgetary regulation, as well as the real economic, political, and social situation in the region.

In our opinion, the second stage involves the following measures: conducting negotiations between groups and participants in order to prioritize projects; establishment of the Budget Committee, whose function is to assess the efficiency of the allocation of resources priorities; as well as discussing and voting for the draft budget.

The main objective of the third stage should be the preparation of technical plans and contracts by local authorities. At this stage, detailed planning, defining technical tasks, tender conditions, tendering procedures and selection of projects, the order of implementation of selected projects should be carried out.

It is also worth noting that local authorities should provide periodic reports on the implementation of the community budget. These reports should include the status of implementation of projects and problems that occurred during their implementation.

All of the above made it possible to develop a cycle of implementation of Participatory Budgeting as an element of decentralization of local budget expenditures, which is shown schematically in Fig. 4.

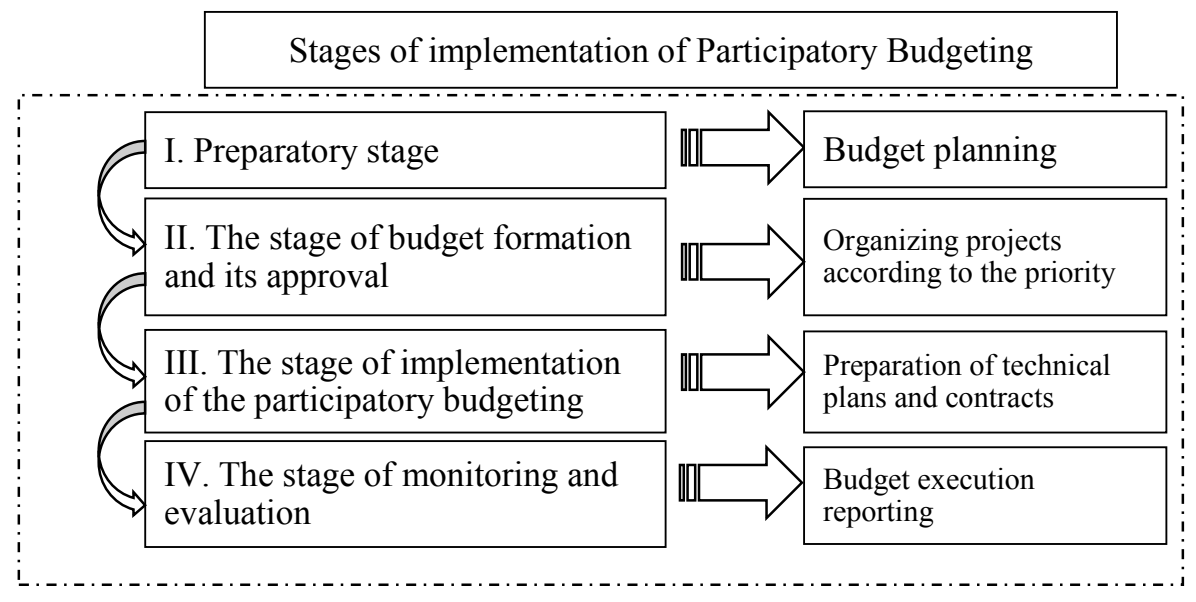

Figure 3. Stages of implementation of Participatory Budgeting

Source: prepared by the author 


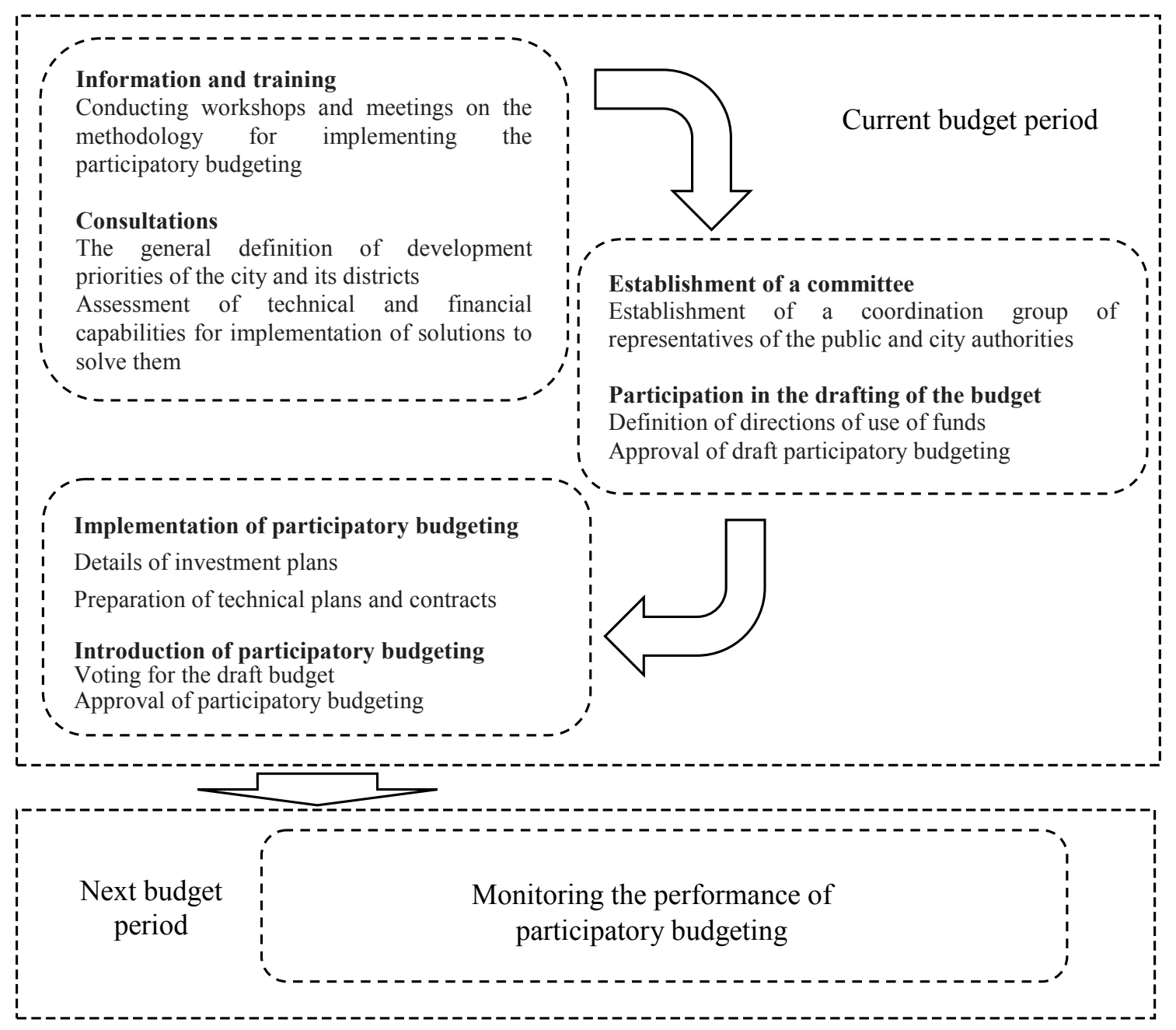

Figure 4. The cycle of implementation of Participatory Budgeting

Source: prepared by the author

\section{Conclusions}

Summing up, it should be noted that for the effective implementation of participatory budgeting in Ukraine, the following is necessary:

Firstly, the introduction and implementation of this instrument require regulatory support and support from state authorities, which will not block public initiatives and procedures and will be ready to refuse to exercise a part of its powers in favour of citizens.

Secondly, we believe that the mechanism of participatory budgeting can function effectively only in a civic, socially responsible society, which will want and have a real opportunity to participate in them.

The last important element is the available financial resources for the implementation of planned projects, selected by the citizens. At the same time, the right of citizens to participate in the adoption of budget decisions can be fully realized when a certain amount of budgetary funds is allocated in the general budget of the administrative-territorial unit for the exclusive disposal of citizens.

\section{References:}

Lunina, I. (2014) Budget decentralization: the goals and directions of reforms. Ekonomika Ukrainy (Economic of Ukraine), 11(636), 61-75 (in Ukr.)

Belets Zh.A. (2016) Participatory Budgeting as an Innovative Democratic Instrument of Citizen Participation in the Management of Territorial Communities, 1, [Electronic resource]. Retrieved from: http: //nbuv.gov.ua/ UJRN/Ttpdu_2016_1_21

Hrynchuk N. (2016) Budgetary process at the local level in Ukraine: legal regulation, powers of local authorities, public participation: 45 .

Demianchuk O.I. (2016). Innovative methods of management of local budgets of Ukraine, 21(1): 190-194. 
Kravchenko T. (2015). Innovative tools for citizens to exercise their right to participate in local self-government in Ukraine, 14 [Electronic resource]. Retrieved from: http://www. dridu.dp.ua/zbirnik/2015-02(14)/22.pdf.

Demianyshyn V. (2017). Conceptual bases of the budgetary mechanism of socio-economic development of the state, 1: 77-88.

Participatory budgeting in the cities of Ukraine: regional section [Electronic resource]. Retrieved from: http://ngonetwork.org.ua

Analysis of Social Voting [Electronic resource]. Retrieved from: https://www.voting.in.ua/votings/gromadskiybyudzhet-mista-kharkiv-na-2018-rik

Buletsa N.V. (2016) Features of the process of participatory budgeting in Ukraine, 6: 159-165. 